\title{
Faith-based Organizations and Microfinance: A Literature Review
}

\author{
Najmul Hoda ${ }^{1} \&$ Shankar Lal Gupta ${ }^{2}$ \\ ${ }^{1}$ College of Business, Umm Al-Qura University, Makkah, Saudi Arabia \\ ${ }^{2}$ Waljat College of Applied Sciences, Rusayl, Oman \\ Correspondence: Najmul Hoda, College of Business, Umm Al-Qura University, Makkah, Saudi Arabia. Tel: \\ 96-653-346-5852. E-mail: najmulhoda19@hotmail.com
}

Received: November 5, 2014 Accepted: December 29, 2014 Online Published: April 2, 2015

doi:10.5539/ass.v11n9p245 URL: http://dx.doi.org/10.5539/ass.v11n9p245

\begin{abstract}
Development institutions have been categorized as faith-based and mainstream based on their background and characteristics. This paper reviews the extant literature on Faith-based Organizations (FBOs) and their role in various areas of development specially poverty alleviation through microfinance. This paper reviews the studies dealing with faith-based organizations, their characteristics and their role in development. Some papers specifically deal with the religious principles that shape the value system in these organizations. A number of empirical studies both qualitative and quantitative provide insights on the working and performance of FBOs. This review paper will be useful for the researchers involved in the areas of social science, anthropology as well as economics. The findings of the empirical studies will be of interest to policy makers and regulators.
\end{abstract}

Keywords: faith-based organizations, microfinance, religion, poverty alleviation, literature review

\section{Introduction}

The development sector has been evolving and has seen a paradigm shift. In the recent past, the sector saw renewed efforts from those development institutions that subscribe to some religious faith and were not acknowledged in the past for some reasons. The development literature clearly distinguishes between the organizations associated with a religious faith and those that claim to be secular. Faith-based microfinance possesses the same distinct features as that of faith-based organizations. Therefore the paper first presents the detailed summary of the features of these organizations found in the literature. While describing the features of faith-based organizations (FBOs), the distinguishing principles, influence of faith, typology, and the role of FBOs in development. The next section deals with the various researches dealing with the principles of religious faiths in dealing with poverty. The next section discusses the studies on the role of the FBOs in poverty alleviations. The final section concludes the paper and discusses scope for future research.

\section{Faith-based Organizations}

Faith-based Organizations have been defined as a "general term used to refer to religious and religion-based organizations, places of religious worship or congregations, specialized religious institutions, and registered and unregistered non-profit institutions that have religious character or missions" (Woldehanna, et al., 2005, p. 27). Though faith-based organization is not a legally defined term, it normally refers to organizations affiliated to certain faith. Clarke (2008) offered a comprehensive definition of Faith-based organizations:

"a faith-based organization is any organization that derives inspiration and guidance for its activities from the teachings and principles of the faith or from a particular interpretation or school of thought within that faith" (p. 6).

These organizations explicitly claim a religious motive (Kirmani \& Zaidi, 2010) and religion in these organizations "are often expressed in their mission statements, outlining the overall purpose of the NGOs and describing the underlying values and principles" (Petersen, 2010). Fritz (n. d.) has included various types of institutions in the list of FBOs: "a religious congregation (church, mosque, synagogue, or temple); an organization, program, or project sponsored/hosted by a religious congregation (may be incorporated or not incorporated); a nonprofit organization founded by a religious congregation or religiously-motivated incorporators and board members that clearly states in its name, incorporation, or mission statement that it is a 
religiously motivated institution; and a collaboration of organizations that clearly and explicitly includes organizations from the previously described categories".

\subsection{Identification of Faith-based Organizations}

There are several studies that point out the characteristics that help in identifying faith-based organizations. Jeavons (1997) proposed seven dimensions and these were also enumerated by Sider and Unruh (2004) as, "organizational self-identity, selection of organizational participants (staff, volunteers, funders, and clients), sources of resources, goals, products, and services (including "spiritual technologies"), information processing and decision making (e.g., reliance on prayer and religious precepts for guidance), the development and distribution of organizational power, and organizational fields (including program partners)" (p. 111). Smith and Sosin (2001) also analyzed several institutions to study how faith is present in an organization and suggested that the presence of faith can be found in the form of "resource dependency, authority and organizational culture". The availability of funds, control of religious institutions or personalities, the influence of faith in the organizational design are some of the important factors that they found to be shaping the uniqueness of faith-based organizations.

\subsection{Influence of Faith in FBOs}

Many researchers have analyzed specifically the influence of faith in the faith-based organizations. Faith has a very strong and distinct influence in the functioning of Faith-based organizations. Clarke (ibid) suggests that faith can influence the agency and identity of the organization along both organizational and programmatic levels. The understanding of "faith" varies within different organizations and this factor is responsible for determining how faith will affect the functioning of an organization. Clarke (ibid) opines on this issue that, "the faith element of the FBO is not an add-on to its development activity rather an essential part of that activity, informing it completely" (p. 15). Berger (2003) further emphasized another important point that the effect of faith cannot be simply identified by programmes. It is actually the motive and the values that make the entire effort faith-based. Jeavons (2004) pointed to this fact in his case study that the effect of "faith" must not be apparent to prove that it exists within the organization. Berger ( $\mathrm{ibid}$ ) also suggests that to understand the effect of faith, pervasiveness should be the main determinant and there is nothing absolute in role of faith in FBOs.

James (2009) found two areas where the influence of faith can be directly observed - in the application of religious ritual and activities and use of religious teaching in main activities. Unruh (2004) highlighted the main factors present in the programmes of a religious organization. These factors are responsible for giving the organization a distinct identity compared to the mainstream organization. He mentions nine features that may indicate religious affiliation. These are "self-descriptions, sacred objects, invitations to religious activities, prayer, use of sacred texts, worship, sharing of personal testimonies, religious teachings, and invitations to a personal faith commitment". Ebaugh et al. (2006) suggest examining the religious nature of FBOs in terms of three dimensions namely Service, Staff, and Organizational dimensions. Goggin and Orth (2002) advanced the earlier works on faith-based organizations and developed a scale named as Faith Integration Scale. This scale could measure the pervasiveness of faith in an organization. The scale comprised of five calibrations - organization, administration, environment, funding, and programme. Each factor was further elaborated to specify its composition. Aiken (2010) emphasized the effect of faith on six areas of the target community namely "change in the community; theology and development goals; selection of beneficiaries; programme design and implementation; staff motivation and faith in internal practice". She also mentioned that faith was also cited to be the main source of motivation by the staff of a faith-based organization. Smith and Sosin (ibid) did an institutional analysis to describe the religious coupling in an organization that can be determined by resource dependency authority and organizational culture. James (2004) deduces from his study on Christian FBOs that faith impacts organizational dynamics in ten ways namely, "structural affiliation and governance; values and staff motivation; mission; strategy and theory of development; selection of partners and choice of beneficiaries; faith practices and teaching in programming; staffing and leadership; organisational culture and decision-making; constituency and sources of funding; and external relationships" (p. 12). Faith affects the organization in two main ways: in the organizational features and in the programme features.

A Faith-based organization may not necessarily have all the characteristics discussed above or meet all the criteria to be identified as faith-based. James (ibid) points out that faith can affect an organization in "internal operations, leadership, relationships, culture and policies of an organization". Jeavons (1994) mentioned that the religious practices observed by the staff are important elements in the organization decision-making. The beneficiaries or members may or not be a part of such rituals. Typical example of the staff religious practice within an organization is the time off for observing religious duty/prayer. Another symbolism is the start of any 
meeting or important work with the recitations from the religious books. The intensity of observation of such acts depend on the influence of faith in the organization. So, in a highly involved organization, it may be mandatory for the staff to attend the prayers or rituals whereas it may be voluntary in other cases.

Table 1. Influence of Faithin FBOs

Sider and Unruh (2004) Organizational Characteristics (Mission statement, Founding Affiliation, Controlling board, Senior management Support, Personnel religious practices)

Programme Characteristics (Religious environment, Program content, Integration of religious component, Expected connection between religious content and desired outcome

Jeavons $(1997,2004)$ organizational self-identity, selection of organizational participants (staff, volunteers, funders, and clients), sources of resources, goals, products, and services (including "spiritual technologies"), information processing and decision making (e.g., reliance on prayer and religious precepts for guidance), the development and distribution of organizational power, and organizational fields (including program partners)

Smith and Sosin (2001) resource dependency, authority and organizational culture

Berger (2003) Not only in programmes but pervasiveness of faith

Unruh (2004)

Self-descriptions, sacred objects, invitations to religious activities, prayer, use of sacred texts, worship, sharing of personal testimonies, religious teachings, and invitations to a personal faith commitment

Ebaugh et al. (2006) Service, Staff, and Organizational dimensions

Goggin and Orth (2002)

Faith Integration Scale (organization, administration, environment, funding, and programme)

Aiken (2010) change in the community; theology and development goals; selection of beneficiaries; programme design and implementation; staff motivation and faith in internal practice

James (2004)

structural affiliation and governance; values and staff motivation; mission; strategy and theory of development; selection of partners and choice of beneficiaries; faith practices and teaching in programming; staffing and leadership; organisational culture and decision-making; constituency and sources of funding; and external relationships

Source: Literature Survey

\subsection{Typology of FBOs}

Faith-based Organizations (FBOs) are not similar, homogenous lot. They vary in several dimensions as discussed in the previous section. More detailed explanations of the variations are present in various studies (Sider \& Unruh, 2004; Clarke, 2008; Hefferan et al., 2009). However, there is one thing common among these organizations and that is the connection with faith. All the faith-based organizations have a clear connection with some religious or faith-tradition but in varying degrees. The variation is not just in degrees of affiliation but also by the virtue of differences within the faith. There are different strains of the same religious faith (Clarke, 2008). Due to this reason, several faith-based organizations hide their faith-identity. James (2009) mention that in order to enlarge the source of donations and diversify the personnel and to be able to work in diverse areas, some faith-based organizations do not use faith too explicitly. There are many classifications and typologies of faith-based organizations available (Table 2). However in terms of the nomenclature of the types of faith-based organizations the contributions of Goggin \& Orth (2002) and Scott (2002) have been given great importance by Sider and Unruh (ibid). Monsma (1996) developed a "Religious Practices Scale" to describe the religiosity of an FBO. On the basis of the degree of religiosity, he called them High, Medium or Low faith-based. Monsma (2002) refined this classification in his later work and classified them as "faith-based or integrated and faith-based or segmented programmes". Sider and Unruh (ibid) classified FBOs into five categories and Tadros (2010, p. 7) has 
cited three types of Faith-based organizations categorized by UNFPA and also presented examples of each types. Clarke (ibid) classified FBOs as, "faith-based representative or apex bodies; faith-based charitable or development organizations; faith-based socio-political organizations; faith-based missionary organizations; and faith-based radical, illegal or terrorist organizations". Bradley (2009) developed a continuum to place faith-based organizations according to how faith shapes their identity and influences their practice. Jodhka and Bora (2009) proposed a modified typology using Clarke's typology (p. 8). Sider et al. (2002) named five typologies based on the presence of distinct religious symbolisms in the programmes.

Table 2. Typology of FBOs

Clarke (2008) faith-based representative or apex bodies; faith-based charitable or development organizations; faith-based socio-political organizations; faith-based missionary organizations; and faith-based radical, illegal or terrorist organizations

\begin{tabular}{ll}
\hline Monsma (1996) & religious practices scale (high, medium or low faith-based) \\
\hline Monsma (2002) & faith- integrated; and faith- segmented programmes \\
\hline Sider (2004) & $\begin{array}{l}\text { faith-permeated; faith-centered; faith-affiliated; faith-background; and } \\
\text { faith-secular partnerships }\end{array}$ \\
\hline
\end{tabular}

Tadros (2010)

faith-based and/or faith-inspired development organizations; interfaithor multi-faith-based organizations; local congregations; and ministries of religious affairs

Bradley (2009) secular non-governmental organizations and denominational or faith-led organizations

Jodhka and Bora (2009) faith-based charitable or development organization; faith-based socio-political organizations; faith-based missionary organization; faith-based cultural organizations; and any other faith-based organization

Sider, et al. (2002)

integrated-mandatory, integrated-optional, relational, invitational and implicit

Source: Literature Survey

\subsection{Significance of FBO's in Development}

Jones and Petersen (2011) present review of the literatures on FBOs in their article. They comment "that there is a growing body of research on religion and development, primarily from development scholars and practitioners". FBOs have been providing "education, health, humanitarian relief, and microfinance to hundreds of millions of people, substituting for absent governments across large swathes of the developing world" (Kaplan, 2009). Tadros ( ibid) present the various types of works being carried out by FBOs that constitute almost half of all the efforts. Tyndale (2006) has supported the role of FBOs in development and proposes that these organizations can prove to be an effective alternative to the mainstream counterparts. Narayan (2000) has also reported that FBOs are contributing more to development and have shown to be more effective. Lunn (2009) and Lybbert (2008) further add that FBOs play an important role in the formation of social capital. Marshall and Keough (2004) opine that these organizations have more affinity to the local people and have the potential to reach the grassroots. Clarke and Jennings (ibid) argue that religious organizations are rooted in the community, a rootedness that helps situate their work and makes them more effective. CIVICUS (2011) highlights that FBOs possess the best network for service delivery because the religious institutions are quite connected to the poor and they play an important role in the lives of the poor. In addition to this network, the FBOs can actually reach the donors of same faith across the world. Another point that adds thrust to the significance of FBOs is the fact that connection with faith is more profound in the developing countries (Goulet, 1980). James (ibid), Belshaw et al. (2001) and Haynes (2007) have highlighted the institutional advantages of FBOs. Wrigley (2011) mentioned several advantages namely "sustainable, efficient development services" "access to the poorest" "valued by the poorest"; "superb networks and global links"; and effective in "motivate (ing) volunteers, action and civil society advocacy" (p. 8). Tsele (2001) mentions that FBOs have positive connections with the poor because they try to relate with the target as "subjects" and not "objects". UNFPA (2008) advocates the role of faith and chalks out a 
strategy on how the government agencies and donors can partner with FBOs. Aiken (ibid) has noted many significant benefits of FBOs citing the works of (James, 2009; Clarke, 2008; Benn, 2005; Marshall, 2005) such as; "providing efficient, cost effective services, reaching the poorest, being valued and listened to by the poor, providing an alternative to a secular theory of development, igniting civil society advocacy and motivating action" (p. 3).

\section{Empirical Studies on Faith-based Microfinance}

Empirical studies dealing with faith-based microfinance are few. Vidal (2001) mentions that the main reason for the scarcity of empirical analyses of these organizations is the absence of any listing of such organizations at international, country or even state/county level. Still, the literature survey resulted in some prominent studies on these institutions.

The conceptual aspects such as the role of faith in development, viability of FBOs in microfinance, significance of religion in micro-entrepreneurship have found due importance by many researchers. Ashta and De Silva (2011) reviewed the studies that took place on the role of religion in microcredit. They also described the broad contours of research in this area. Akdede and Hotunluoglu (2008) analyzed empirically the relationship between "the degree of religiosity" and "economic development" for Turkish cities with the presence of municipal authorities. Allen (2006) has discussed the potential of faith-based microfinance institutions in providing better access to financial services to very poor people than groups which borrow from banks and financial institutions. van Engelenhoven (2006) in his thesis examined the relationship between religion and economic activities of micro-entrepreneurs in developing countries who receive a micro-credit in Zambia. He finds that the female micro-entrepreneurs in developing countries are central and there is a positive relationship between religion and micro-entrepreneurship.

In-depth analyses of the functioning, operating procedures and faith pervasiveness in FBOs are also found in the literature. Harper, et al. (2008) discusses FBOs based on Islamic, Hindu and Christian faiths. Shetty (2008) has also discussed the same faith-based microfinance institution associated with the Dharmasthala temple in Dakshin Kannada in the southern part of India included in Harper, et al. (ibid). Diklitch and Rice (2004) describe faith-based microfinance institutions in Africa. They mention about Menonite Central Committee as a different and more liberal Christian approach to development assistance. Harriman (2008) presents such institutions in Philippines and Thailand. Kaur (2007) analyzed the activities of COVA of Hyderabad, India. Mask (2000) writes about the microfinance operations of World Relief in his paper. Ashta and Deselva (ibid) have cited the case of Periyar community that runs microfinance institution named SNDP Microfinance in Southern India. Kessler and Arkush (2009) highlighted the operating details of a Christian FBO named Christian Aid. Fikkert (2000) describe a Christian FB-MFI named Evangelical Social Action Forum (ESAF) in Kerala, India. Clarke (2010) discusses the unique cases of inter-faith based organizations namely Muslim Aid and United Methodist Committee on Relief to demonstrate that the presence of faith has overall positive effect on the development activities. Bradley (2009) compared three types of faith-based organizations using a faith scale.

The empirical assessment of sustainability, impact, and financial performance of FB-MFIs has been dealt with in some studies. Mersland et al. (2013) analyzed the performance of a sample of Christian faith-based microfinance institutions and compared them with the mainstream organizations. Reinikka \& Svensson (2008) compared the effectiveness of faith-based and mainstream service providers. Their findings favored their assumption that FBOs are more effective than mainstream organizations. Aiken (ibid) examined the influence of faith identity in FBOs and found that it is a determining factor for the success of these programmes. Benthall (2008) supported the view that the relationship between faith and development is positive. Mc Keon and Madsen (2009) research and document the roles faith-based organizations (FBOs) are playing in Western Canada, especially in British Columbia and Alberta. Ndemo (2006) provides an in-depth analysis of the performance of faith-based enterprises operating in Kenya while Jodhka and Bora (ibid) provide an empirical analysis of the FBOs operating in the state of Maharashtra in India. The research is a part of a comprehensive study instituted by DFID. Bano and Nair (2007) provide a comprehensive analysis of the FBOs operational in South Asia. Noland (2005) presented the performance of economies that have influence of religion and this study has significant relevance to the study of FBOs. Llanto and Geron (2000) studied the operational features of FB-MFIs and commented on some important issues like the coverage of cost of offering non-monetary services like faith-teaching, spiritual activities etc. Fikkert (ibid) presented an in-depth analysis of various Christian FB-MFIs and suggested that the teachings of Gospel should be highlighted more in any humanitarian work undertaken by Christian FB-MFIs. He basically promotes faith-integrated institutions. Hovland (2005) analyses the tensions between the Norwegian Missionary Society and its dependence on secular funding from NORAD, the Norwegian government's official development assistance agency. 
Table 3. List of faith-based microfinance institutions

\begin{tabular}{|c|c|c|c|c|}
\hline S No & Name of the institution & Reported in & Faith & Location \\
\hline 1. & SNDP & Minimol and Makesh (2012) & Hinduism & India/Kerala \\
\hline 2. & Akhuwat & Harper et al. (ibid) & Islam & Pakistan/Lahore \\
\hline 3. & Al Farz Foundation & Khaled (2011) & Islam & Pakistan/Lahore \\
\hline 4. & Al Khair Cooperative Credit Society & Khan (2009) & Islam & India/Patna \\
\hline 5. & $\begin{array}{l}\text { American Friends Service Committee } \\
\text { (AFSC) }\end{array}$ & Diklitch and Rice (2004) & Christianity & United States \\
\hline 6. & CAPARV & Harper et al. (ibid) & Islam & India/Imphal \\
\hline 7. & Catholic Relief Services & $\begin{array}{l}\text { Harper et al. ( ibid ), Diklitch and } \\
\text { Rice (2004) }\end{array}$ & Christianity & Various Countries \\
\hline 8. & Chinmaya Mission Sidhabari & Paul (2012) & Hinduism & India/Sidhabari \\
\hline 9. & Christian Aid & $\begin{array}{l}\text { Kessler and Arkush (2009), } \\
\text { Harper et al. (ibid) }\end{array}$ & Christianity & UK/Oxford \\
\hline 10. & COVA & Harper et al. ( ibid ), Kaur (2007) & Islam & India/Hyderabad \\
\hline 11. & ESAF & Harper et al. ( ibid ) & Christianity & India/Chennai \\
\hline 12. & Islamic Relief Worldwide & $\begin{array}{l}\text { De Cordier (2009), } \\
\text { Kirmani and Khan (2008) }\end{array}$ & Islam & UK/London \\
\hline 13. & LEAP & Harper et al. ( ibid) & Christianity & Liberia/Monrovia \\
\hline 14. & Lutheran World Relief (LWF), & Diklitch and Rice (2004) & Christianity & USA \\
\hline 15. & Mennonite Central Committee (MCC) & Diklitch and Rice (2004) & Christianity & North America \\
\hline 16. & Muslim Aid & Clarke (2008) & Islam & UK/London \\
\hline 17. & Muslim Fund, Deoband & Khan and Nisar (2004) & Islam & India/Deoband \\
\hline 18. & Oxfam & Bradley (ibid) & Christianity & UK/Oxford \\
\hline 19. & $\begin{array}{c}\text { Shri Kshetra Dharmasthala Rural } \\
\text { Development Program }\end{array}$ & $\begin{array}{l}\text { Harper } \text { et al. (2008), Ashta (2010), } \\
\text { Shetty (2008) }\end{array}$ & Jainism & India/Mangalore \\
\hline 20. & Tearfund & Wrigley (2011) & Christianity & UK/Teddington \\
\hline 21. & The Holy Cross Social Service Centre & Harper et al. (2008) & Islam & India/Hazaribagh \\
\hline 22. & United Methodist Committee on Relief & Clarke (2008) & Christianity & USA/New York \\
\hline 23. & Village Development Project & Bradley (2009) & Hinduism & India/Jodhpur \\
\hline 24. & World Jewish Relief & Kessler and Arkush (2009) & Jewism & UK/London \\
\hline 25. & World Vision & Diklitch and Rice (2004) & Christianity & USA \\
\hline
\end{tabular}

Source: Literature Survey

\section{Discussions and Conclusions}

Faith and development have been operational for a long time but their association was subdued because of the existing taboo. However, the need for alternative models of poverty alleviation and the gigantic task of eliminating poverty, enshrined in Millennium Development Goals, has opened the doors for this model. In the past few decades, the literature on Faith-based organizations has appeared in significant amount. These organizations have the potential of adding a lot of value in the area of microfinance in the form of social capital, linkage with the community, reputation and cost efficiency. The literature review shows that there are limited studies on the detailed performance of these faith-based microfinance institutions. Comparisons of the performance of faith-based microfinance institutions with their mainstream counterparts are very few. The various aspects that need to be probed are the sustainability of these institutions, impact of faith, value addition to microfinance, and the inherent challenges.

\section{References}

Aiken, A. (2010). Assessing the Impact of Faith: A Methodical Contribution. Praxis Note No. 55, INTRAC. Retrieved from http://www.prismaweb.org/media/196125/praxis-note-55-assessing-the-impact-of-faith.pdf

Akdede, S. H., \& Hotunluoglu, H. (2008). Economic development and religiosity: An investigation of Turkish. International conference on economic issues in a globalizing world, Izmir.

Allen, H. (2006). Village Savings and Loans Associations - sustainable and cost-effective rural finance. Small Enterprise Development, 17. http://dx.doi.org/10.3362/0957-1329.2006.009 
Ashta, A., \& De Selva, R. (2011). Religious practice and microcredit: literature review and research directions. Postmodern Openings, 2(8), 33-44.

Ashta, A. (2010). Hinduism and Microfinance, electronic copy. Retrieved from http://papers.ssrn.com/ sol3/papers.cfm?abstract_id=1728384\&http://papers.ssrn.com/sol3/papers.cfm?abstract_id=1728384

Bano, M., \& Nair. P. (2007). Faith-based organisations in South Asia: Hhistorical evolution, current status and nature of interaction with the state. Working Paper 12-2007, Religions and Development Research Programme, University of Birmingham. Retrieved July 2, 2010, from http://www.rad.bham.ac.uk/files/ resourcesmodule/@random454f80f60b3f4/1202734559_WP12.pdf

Belshaw, D., Calderisi, R., \& Sugden, C. (2001). Faith in Development. Regnum: Oxford. http://dx.doi.org/10.1596/0-8213-4848-5

Benthall, J. (2008). The Palestinian Zakat Committees 1993-2007 and their contested interpretation. PSIO Occasional Paper. 1/2008 Geneva.

Berger, J. (2003). Religious Nongovernmental Organizations: An Exploratory Analysis, Voluntas. International Journal of Voluntary and Nonprofit Organizations, 14(1), 15-39(25). http://dx.doi.org/10.1023/A: 1022988804887

Bradley, T. (2009). A Call for Clarification and Critical Analysis of the Work of Faith-based Development Organisations (FBDO). Progress in Development Studies, 9(2), 101-114. http://dx.doi.org/10.1177/ 146499340800900202

Naidoo, K. (2000). The Charities Aid Foundation, CIVICUS. Alliance, 5(1).

Clarke, G. (2008). Faith-based Organisations and International Development. In Clarke \& Jennings (Eds.), Development, Civil Society and Faith-Based Organisations- Bridging the Sacred and the Secular. London, Palgrave.

Clarke, G. (2010). Trans-faith humanitarian partnerships: the case of muslim aid and the united methodist committee on relief. European Journal of Development Research, 22, 510-528. http://dx.doi.org/10.1057/ejdr.2010.22

De Cordier, B. (2009). Faith-based aid, globalisation and the humanitarian frontline: an analysis of Western-based Muslim aid organizations. Disasters. Overseas Development Institute. http://dx.doi.org/10.1111/j.1467-7717.2008.01090.x

Dicklitch, S., \& Rice, H. (2004). The Mennonite Central Committee (MCC) and faith-based NGO aid to Africa. Development in Practice, 14(5). http://dx.doi.org/10.1080/0961452042000239805

Ebaugh, H. R., Chafetz, J. S., \& Pipes, P. F. (2006). Where's the faith in faith-based organizations? Measures and correlates of religiosity in faith-based social service coalitions. Social Forces, 84, 2259-2272. http://dx.doi.org/10.1353/sof.2006.0086

Fikkert, B. (2003). Christian Microfinance: Which way now?. Working Paper 25, presented at the $20^{\text {th }}$ anniversary conference of the Association of Christian Economists, Washington.

Fritz, J. (n. d). What Is a Faith-Based Nonprofit? Retrieved from http://nonprofit.about.com/od/faqsthebasics/f/ What-Is-A-Faith-Based-Nonprofit.htm

Goggin, M. L., \& Orth, D. A. (2002). How Faith-based and Secular Organizations Tackle Housing for the Homeless. Albany, NY: The Roundtable on Religion and Social Welfare Policy.

Goulet, D. (1980). Development Experts: The One Eyed Giants. World Development, 8, 481-489. http://dx.doi.org/10.1016/0305-750X(80)90033-9

Harper, M., Rao, D. S. K., Sahu, A. K. (2008). Development, Divinity and Dharma - The role of religion in development and microfinance institutions. Practical Action Publishing, Warwickshire.

Haynes, J. (2007). Religion and Development: Conflict or Cooperation? Palgrave Macmillan, Basingstoke. http://dx.doi.org/10.1057/9780230589568

Hefferan, T., Adkins, J., \& Occhipinti, L. A. (Eds.). (2009). Bridging the Gaps: Faith-Based Organizations, Neoliberalism, and Development in Latin America and the Caribbean. Lexington University.

Hovland, I. (2005). Who's afraid of religion? Proceedings of the Development Studies Association Conference, Development Studies Association, Milton Keynes. Retrieved from http:/th-th.facebook.com/note.php? note_id $=46995596868$ Tuesday, 
James, R. (2004). Creating Space for Grace- God's power in Organisational Change. Swedish Mission Council, Stockholm. Retrieved from http://www.missioncouncil.se/download/18.25948b3d117af90ec978000388/04_ 02_space_for_grace.pdf

James, R. (2009). What is Distinctive about FBOs? How European FBOs Define and Operationalise their Faith. Praxis Paper 22, INTRAC.

Jeavons, T. H. (1994). When the bottom line is faithfulness: Management of Christian service organizations. Indianapolis: Indiana University Press.

Jeavons, T. H. (1997). Identifying characteristics of "religious" organizations:An exploratory proposal. In J. Demerath III, P. D. Hall, T. Schmitt, \& R. H. Williams (Eds.), Sacred companies: Organizational aspects of religion and religious aspects of organizations (pp. 79-95).NewYork: Oxford University Press.

Jeavons, T. H. (1998). Identifying Characteristics of "Religious" Organizations: An Exploratory Proposal. In N. J. Demerath III, P. D. Hall, T. Schmitt, \& R. H. Williams (Eds.), Sacred Companies: Organizational Aspects of Religion and Religious Aspects of Organization (pp. 79-95). Oxford University Press, New York.

Jeavons, T. (2004). Religious and Faith-Based Organisations: Do We Know One When We See One? Non-Profit and Voluntary Sector Quarterly, 33(1), 140-145. http://dx.doi.org/10.1177/0899764003257499

Jodhka, S. S., \& Bora, P. (2009). Mapping faith-based development activities in contemporary Maharashtra, India. Religions and Development Research Programme. Working Paper 28. International Development Department, University of Birmingham. Retrieved from http://www.religionsanddevelopment.org/files/ resourcesmodule/@random454f80f60b3f4/1249395995_working_paper_28.pdf

Jones, B., \& Petersen, M. J. (2011). Beyond faith-based organizations: critiquing recent work on religion and development. Third World Quarterly, (7).

Kaplan, S. (2009). Faith and fragile states: why the development community needs religion. Harvard International Review, 31(1).

Kaur, T. (2007). Burqa-clad and empowered. India Together. Hyderabad, May.

Kessler, E., \& Arkush, M. (n. d). Keeping Faith in Development, Wolf Institute. Retrieved from http://www.woolf.cam.ac.uk/uploads/keeping\%20faith\%20in\%20development.pdf

Karim, N., \& Khaled, M. (2011). Taking Islamic microfinance to scale. CGAP. Retrieved from http://www.cgap.org/ blog/ taking-islamic-microfinance-scale

Khan, J., \& Nisar, S. (2004). Collateral (Al-Rahn) as Practiced by Muslim Funds of North India. Journal of King Abdul Aziz University - Islamic Economics, 17(1), 17-34. http://dx.doi.org/10.4197/islec.17-1.2

Khan, M. S. (2009). Al-Khair Cooperative Credit Society: A Working Model of Interest-free Microfinance. Retrieved from http://www.radianceweekly.com/167/4045/it039s-bare-discrimination-nay-hate-but-what03 9s-the-solution/2009-08-16/microfinance/story-detail/al-khair-cooperative-credit-societya-working-model-o f-interest-free-microfinance.html

Kirmani, N., \& Khan, A. A. (2008). Does Faith Matter? An Examination of Islamic Relief's Work with Refugees and Internally Displaced Persons. Refugee Survey Quarterly, 27(2), 41-50. http://dx.doi.org/10.1093/rsq/ hdn 032

Kirmani, N., \& Zaidi, S. (2010). The Role of Faith in the Charity and Development Sector in Karachi and Sindh, Pakistan. Birmingham. Religions and Development Working Paper 50.

Llanto, G., \& Geron, M. P. (2000). Can Christian Microfinance Institutions Pursue Kingdom Building Activities and Remain Viable? Centre for Community Transformation, Manila.

Lunn, J. (2009). The Role of Religion, Spirituality and Faith in Development: A critical theory approach. Third World Quarterly, 30(5), 937- 951. http://dx.doi.org/10.1080/01436590902959180

Lybbert, T. (2008). Exploring the role of spiritual capital in poverty traps and microfinance. Faith \& Economics, 51(Spring), 57-79. Retrieved from https://www.gordon.edu/ace/pdf/F\&EArticlesSpring08.pdf

Marshall, K., \& Keough, L. (2004). Mind, Heart, and Soul in the Fight against Poverty (Washington, D.C.: The World Bank).

Mask, R. P. (2000). Christian microenterprise development: counting the cost and building the kingdom. Covenant College, Lookout Mountain, GA. 
Mc Keon, B., Rodrigo, J., \& Madsen, C. (2009). Faith-based organizations engaged in the Social Economy in Western Canada. BALTA, Canada. Retrieved from http://auspace.athabascau.ca/bitstream/2149/2523/1/ BALTA $\% 20$ A4\%20-\%20FBO\%20\&\%20SE\%20-\%20Final\%20Report.pdf

Mersland, R., D'Espallier, B., \& Supphellen, M. (2013). The effect of religion on development efforts: Evidence from the microfinance industry and a research agenda. World Development, 41(c), 145-156. http://dx.doi.org/10.1016/j.worlddev.2012.05.030

Minimol, M. C., \& Makesh, K. G. (2012). Empowering rural women in Kerala: A study on the role of Self Help Groups (SHGs). International Journal of Sociology and Anthropology, 4(9), 270-280. http://dx.doi.org/10.5897/IJSA12.003

Monsma, S. (1996). When Sacred and Secular Mix: Religious Nonprofit Organizations and Public Money. Rowman Littlefield, USA.

Monsma, S. V. (2002). Working Faith: How Religious Organizations Provide Welfare-To-Work Services. CRRUCS Report, Philadelphia: University of Pennsylvania, Center for Research on Religion and Urban Civil Society. Retrieved from http://www.manhattan-institute.org/pdf/crrucs_working_faith.pdf

Narayan, D. (2000). Voices of the Poor: Can Anyone Hear Us? Washington, World Bank. http://dx.doi.org/10.1596/0-1952-1601-6

Ndemo, E. B. (2006). Assessing sustainability of faith-based enterprises in Kenya. International Journal of Social Economics, 33(5/6).

Noland, M. (2005). Religion and Economic Performance. World Development, 33(8), 1215-1232. http://dx.doi.org/10.1016/j.worlddev.2005.03.006

Paul, N. (2012). CORD's Case Study on Inclusive and Sustainable Rural Development in India. International Journal of Academic Conference Proceedings, 1(2).

Petersen, M. J. (2010). International Religious NGOs at The United Nations: A Study of a Group of Religious Organizations. The Journal of Humanitarian Assistance. Retrieved from http://sites.tufts.edu/jha/ $\operatorname{archives} / 847$

Reinikka, R., \& Svensson, J. (2008). Working for God? Evidence from a change in financing of not-for-profit health care providers in Uganda. The World Bank.

Scott, J. D. (2002). The scope and scale of faith-based social services. Albany, NY: The Roundtable on Religion and Social Welfare Policy. The Pew Charitable Trusts. Retrieved from http://www.rockinst.org/pdf/faithbased_social_services/2003-06-the_scope_and_scale_of_faith-based_social_services_a_review_of_the_res earch_literature_focusing_on_the_activities_of_faith-based_organizations_in_the_delivery_of_ social_services.pdf

Shetty, N. K. (2008). The Microfinance Promise in Financial Inclusion and Welfare of the Poor: Evidence from Karnataka, India. ISEC Working Paper 205.

Sider, R., \& Unruh, H. (2004). Typology or Religious Characteristics of Social Service and Educational Organisations and Programs. Non-profit and Voluntary Quarterly, 33(1), 109-134. http://dx.doi.org/10.1177/ 0899764003257494

Sider, R. J., Olson, P. N., \& Unruh, H. R. (2002). Churches that Make a Difference. Grand Rapids, MI:Baker Books

Smith, S. R., \& Sosin, M. R. (2001). The Varieties of Faith-Related Agencies. Public Administration Review, 61, 651-670.

Tadros, M. (2010). Faith-Based Organizations and Service Delivery Some Gender Conundrums. Gender and Development Programme. Paper Number 11, United Nations Research Institute for Social Development. Retrieved from http://www.unrisd.org/80256B3C005BCCF9/\%28httpAuxPages\%29/592137C50475F6A8 C12577BD004FB5A0/\$file/Tadros.pdf

Tsele, M. (2001). The Role of the Christian Faith in Development. In D. Belshaw, R. Calderisi, \& C. Sugden (Eds.), Faith in Development: Partnership between the World Bank and the Churches of Africa. Washington, D.C.: World Bank and Regnum Books International

Tyndale, W. (Ed.). (2006). Visions of Development, Faith-Based Initiatives. Aldershot: Ashgate.

UNFPA (United Nations Population Fund). (2008). Culture Matters: Lessons from a Legacy of Engaging 
Faith-Based Organizations. Retrieved July 1, 2009, from http://www.unfpa.org/webdav/site/global/shared/ documents/publications/2008/Culture_Matter_II.pdf

Unruh, H. R. (2004). Religious elements of church-based social service programs: Types, variables and integrative strategies. Review of Religious Research, 45(4), 317-335.

van Engelenhoven, B. (2006). Faith and Fortune: Religion and Female Microentrepreneurship (Master Thesis). Radboud University Nijmegen, Netherlands

Vidal, C. (2001). Faith based organizations in Community Development, HUD's Office of Policy Development and Research $(P D \& R)$. U. S. Department of Housing and Community DevelopmentOffice of Policy Development and Research. Retrieved from http://www.nebhands.nebraska.edu/files/Faith\%20Based\%20 Community\%20Development.pdf

Woldehanna, S. (2005). Faith in Action: Examining the Role of Faith-based Organizations in Addressing HIV/AIDS. Global Health Council. Retrieved from http://www.hivpolicy.org/Library/HPP000550.pdf

Wrigley, A. (2011). Who's Afraid of Holistic Development? Navigating the Interface between Faith and Development. Retrieved from http://faithindevelopment.org/doc/Dissertation.pdf

\section{Copyrights}

Copyright for this article is retained by the author(s), with first publication rights granted to the journal.

This is an open-access article distributed under the terms and conditions of the Creative Commons Attribution license (http://creativecommons.org/licenses/by/3.0/). 